\title{
The Effect of Leadership Style on Companies Survival: A Comparison Study Between Chrysler Auto Maker and Jordanian Potash Company
}

\author{
Dr. Zaydoun Faleh Meslem Al Khalafat \\ Universiti sultan zainal abidin
}

\begin{abstract}
This research paper aims at investigating the effect of transformational leadership on a company's survival when such company at the verge of collapse. Leadership style assessment analyses are used with application on a Jordanian leading company" The Arab Potash"(APC), and the American auto maker giant Chrysler. It is unusual practice for researchers to conduct studies on companies which are completely different in every aspect. However, this study found a common ground between a giant and a little tiny company which enable researcher to conduct an effective comparison between the two for the purpose of revealing the impact of good leadership on the company's survival. The history of these two companies is very interesting because of the similarity between the two. In 1970s and 1980s Chrysler and Arab Potash were facing very serious problems, in a degree that they were on their way to bankruptcy and death. Fortunately, two exemplary leaders came for rescue, Lee. Iacocca took over Chrysler, and a distinguished Jordanian took over The Arab Potash. Both leaders did miracles and turned the companies around from failing to profitable corporations. The achievement of those two leaders have manifested the effectiveness of true leadership in creating success and flourishing of hopeless situation. Lee Iacocca and Hamor make this study to be unique because it is the first study of its kind in Jordan to the best of this researcher's knowledge.
\end{abstract}

Keywords: Chrysler, Arab Potash, Lee Iacocca, M.Hamor transformational leadership

DOI: $10.7176 / \mathrm{EJBM} / 11-35-11$

Publication date: December $31^{\text {st }} 2019$

\section{Introduction}

Arab Potash was established in mid 1950s to help the Jordanian economy, but later it became a burden on the Jordanians in general, and it was at the verge of collapse. In mid 1980s a new CEO took over the company. he turned the company around after it was at the verge of bankruptcy. In the other hand, with similar conditions Chryslers auto maker in America in late 1980s was facing bankruptcy, and the advent of CEO lee. Iacocca who saved Chryslers proved that he is a true transformational leader. the same is true about Arab potash company.

Transformational leadership.

Reviewed literature points out that, simple definition and easy answers do not exist in the area of leadership. (Tarawneh 2008) leadership is a complex process by which a person influences other to accomplish a mission, task, or objective and directs the organization in a way that makes it more cohesive and coherent. a person carries out this process by applying leadership attributes: belief, values, ethics, character, knowledge, and skills.

leadership makes people want to achieve high goals and objectives, while bosses simply oblige people to accomplish a task or objective.

leaders and the difference with managers. anyone with proper education and training can be a manager, but not a leader to develop leadership, the focus must be on the four clusters of characteristics that successful and strong leaders have in common: -

Vision, perspective and a clear understanding of the big picture and the ability to organize and empower to achieve results, Strong interpersonal skills, and the ability to communicate, influence and work with others Personal motivation, (Tarawneh 2008)

Transformational Leadership Theory: is the most widely accepted theory today . It is the road map for a company to grow and to flourish. This type of leadership shares five common elements:

Challenge the process - First, find a process that they believe needs to be improved the most. (Jordan Ministry of Industrial and trade 2014)

Inspire a shared vision - Next, share you vision in words that can be understood by your followers. (Al Tarawneh, K. (2008)

Enable others to act - Give them the tools and methods to solve the problem.

Model the way - When the process gets tough, get the hands dirty. A boss tells others what to do, a leader shows it can be done.

There's no such thing as 'can't do'

'Can't do' is an alien concept to a real leader. Leaders get things done. They have commitment, persistence, determination and resilience. Couple all of that with creative problem solving and have a person turns things 
around. Indeed, things might even get shaken up when they're around. It isn't always comfortable being around leaders. (Maxwell, 2013)

We see these qualities of leaders in several personalities, in every field and domain, without such leaders there would be no civilization. (as it is seen in the American president Abraham Lincoln, when he abolished slavery in America, and gave freedom and equality to all African -Americans.

\subsection{Problem of the study}

In order to achieve the objectives of the study, a complete company assessment of the Arab Potash and Chrysler, before and after, their crises is conducted to see in what condition these two companies were, and how these two magnificent leaders did in order to turn things around. Thus, the problem of the study lies in examining the effect of transformational leadership style which saved the two companies from liquidation.

In order to clarify the study's problem, the following questions are answered:

1- On what bases an unmatched comparison is conducted between two entirely different companies: giant Chrysler and tiny Arab Potash?

2- What are the plans and strategies which Lee Iacocca used to save Chrysler?

3- What are the plans and the strategies that Muhammad Hamor used to save Arab Potash?

4- What made these two leaders to be distinguished globally?

\section{Arab Potash company}

According to Amman Stock Exchange statistics (2015) the Arab Potash Company was one of the "big five" companies in Jordan. Arab Potash was established in the 1950s to promote economic development, national sovereignty, and international prestige in Jordan. The Jordanian government provided the capital, appointed the directors, and influenced the selection of managers.

Thus, the enterprises did not have much autonomy, were not profit-oriented, it served as pillars of the patrimonial political system. (Al Tarawneh, K. (2008)) Therefore, one of the Potash problems lies in the company lacks of effective and proper management in a hazardous environment characterized by rapid changes.

Management lacked the best strategy to build sustainable infrastructures in the Anthropocene. In 1982, after the completion of the Arab Potash Company solar evaporation system at the southern sector of the Dead Sea, the very first sinkholes were observed in different places all around the the site of the company or the Lisan Peninsula on the Dead Sea.

In addition, management viewed potash as a rather unglamorous commodity because of its limited applications, low prices, the relatively small size of the industry high barriers to entry. Yet on closer inspection, potash provides an interesting mineral market case study. Potash management was not able to identifying employees' performance and the most important dimensions of improvement the performance efficiency, improvement the employee's performance in the Jordanian Potash Company, and changes of price and production were problems the management could not solve (Hamilton, 2003). In 1978/9, the outbreak of the Iran - Iraqi war caused political unrest which doubled Potash problems. (Kilian, 2008) In addition, Arab Potash cannot compete globally especially against the three largest exporters Canada, Russia and Belarus. These countries produced jointly over 30 million tons of potash or $60 \%$ of world production. (Andrejchuk 2002) All of these problems combined caused Arab Potash to become at the verge of collapse.

\section{New leadership and the rescue:}

Jordan's mining sector is considered the cornerstone to the Jordanian economy. the second largest export of phosphate, the fourth largest producer and the second largest exporter of potash,

In the mining sector in Jordan exports of phosphate and potash is big business, because it is well endowed with high quality and low-cost deposits. The wealth created from such resources will not only benefit government, mining companies, stakeholders and local communities but also phosphate and potash consumers around the world. In Jordan potash industry led the contribution among all mining products; its share was $3.9 \%$ to the estimated GNP

foreign companies were granted the right for mining in many areas of Jordan.

- Jordan has significant mineral resources that are, or could be the basis for several downstream chemical industry clusters: phosphate, potash, silica, uranium, zeolites, skilled labors, infrastructure and solid administrative environment and political stability.

\section{Chrysler Crisis}

The last time Chrysler faced a situation this dire - on the tail end of the 1970s oil crisis. We can summarize Chrysler problems as follow: that there will be no government guarantees, no product to save the day, no turnaround by downsizing alone. A more fundamental strategy shift is necessary. Chrysler has slipped to fifth in sales — behind GM, Ford, Toyota and Honda — in its home market. (Shanks N (2012)

SWOT Analysis

Strength and Weakness:

Had an established American Brand, Carried a lot of assets 
Heavily invested in hard assets, including plant and equipment

A large and skilled manufacturing workforce. Highly leveraged (lots of debt)

Declining sales against the high debt caused a severe cash problem

No financial controls in place. Low investment in R\&D (had gone away from its one-time engineering strength; no new models in the pipeline). Weighed down by many and miscellaneous ventures (many international) Lack of information for decision making was poorly timed (Shanks N (2012)

\section{Chrysler Corporation and the new leadership}

Back from the Ashes Again:

Lee Iacocca found Chrysler in miserable condition:

Low morale - secrets flowed out much too easily. Costly inventory distribution system (had a practice of building thousands of cars that were unsold; would end up having fire sales to get rid of the over stock).

Leased car deals with rent-a-car co, Left them with backload of used cars (upside down assets).

It was Iacocca who made the tough decisions that got the company back on track. He resized the company, secured a significant loan guarantee from the government and introduced the K-Car line of inexpensive, fuelefficient cars. The new products were an expensive hit or miss for Daimler; Chrysler experienced years of up and down profit and loss, ending 2006 in the red. And Daimler, which had laid out \$36 billion in stock for a profitable Chrysler, decided all bets were off.

Chrysler was to focus on cost cutting in the short term and pursue long-term global sales growth along with a product portfolio that included more fuel-efficient, small vehicles.

Iacocca joined Chrysler and began rebuilding the entire company from the ground up, laying off many workers, selling Chrysler's loss-making European

division to Peugeot, and bringing in many former associates from Ford. As the chief executive officer of the Chrysler Corporation, he transformed a dying company into a booming success by leading a fight for survival that has become almost legendary-and made his name a symbol of integrity that millions of Americans know and trust. Iacocca started as Chrysler's chairman, and began a heavy restructuring of Chrysler. At the time Iacocca took over, Chrysler was on the verge of bankruptcy, as it was focusing most of

its money on large, fuel thirsty cars that the public didn't want due to a fuel crisis at the time.

First, Iacocca announced plant closures, job layoffs, and his plans for the company. His next move was cutting several large models, which were heavily unprofitable, and put the subcompact Dodge Omni and Plymouth Horizon into production. The Omni and Horizon became instant hits, selling over 300,000 units each their debut year, showing what was to come for Chrysler. Realizing that the company would go out of business if it did not receive a significant amount of money to turn the company around, Iacocca approached the US Congress in 1979 and asked for a loan guarantee. Congress lent Chrysler the money, the loans. Iacocca arguing that more jobs were at stake if Chrysler stopped operating.

After receiving this reprieve, Chrysler released the first of the Chrysler K Car line, the Dodge Aries and Plymouth Reliant in 1981, compact automobiles based on design proposals that Ford had rejected during Iacocca's time there. Coming right after the oil crisis of the 1970 s, these small, efficient and inexpensive, frontwheel drive cars sold rapidly. In addition, two years later

Chrysler released the minivan and to this day. (Abbah M. / 2014)

Chrysler leads the automobile industry in minivan sales. Because of these three cars, and the reforms Iacocca made, the company turned around quickly and was actually able to repay the government-backed loans seven years earlier than expected; most of it came from cars built on the $\mathrm{K}$ platform. Iacocca was also responsible for Chrysler's acquisition of American Motors in 1987, which brought the profitable Jeep division under Chrysler's corporate umbrella. By this time, AMC had already finished most of the work with the Jeep Grand Cherokee, which Iacocca desperately wanted.( Alnawafleh 2013)

This American legend, the tough-talking, straight-shooting businessman has brought Chrysler back from the brink of bankruptcy and in the process, became a media celebrity and a news maker. Once he said: "If you can find a better car-buy it,"( Alnawafleh 2013)

\section{Opportunities Threats}

Government desire to save jobs and avoid inherent problems of closing a very large domestic employer. A need for new car models and willingness of suppliers and unions to make concessions For Chrysler, Iacocca identified some important stakeholders that he would have to forge a strategic relationship with: the banks, his suppliers and dealers, the unions, the popular press, and even the federal government.( Ramadna 2012)

Lee Iacocca worked on the company needs such as: an efficient productionsystem, product development capability (to deliver fresh, new models) effective and efficient sales distribution (in coordination with dealers) Needs strong marketing capability Now Iacocca has clear direction-the high-level strategy it might look like this:

1. In order to bring unity and cohesion to company, new competent, experienced management team

2. Fix the cash crisis 
3. Develop production design capability so that new model can be introduced.

First, Iacocca fired 33 of the 35 vice presidents and replaced them with people he knew from his vast network in the industry. He had to fix the low morale and the poor management system quickly.

Second, he had to start cutting costs and/or raising cash. Plants, including one in Detroit, were closed. A Just in Time (JIT) inventory system was created with parts suppliers. The annual report was printed sans color, using a plain and shorter report instead. They even sized new model cars so, they fit economically into freight cars (176 inches long were the new K car).( Jenny, F. (2012)

More cost cutting: Cut salaries (Iacocca made a very public admission of taking $\$ 1$ per year salary). Wage concessions took worker salaries from $\$ 20$ to $\$ 17$ and then lower again. There were mass firings of the white collar staff—-saving \$500 million.(Shanks N (2012)

To raise cash, Chrysler sold assets that were not part of their core business-even ones that were making money (the strategy was to focus back on the car business. It even sold valuable assets such as prime dealership property in Kansas - they needed immediate cash. Chrysler sold off all European oper tions. Still needing money nothing worked out mainly because Chrysler was in such bad shape. (Shanks N (2012)

Iacocca went after the government to give Chrysler short-term relief, finally settling on $\$ 1.2$ billion of loan guarantees (which they were paid back fully).Lee Iacocca saved Chrysler after it was dying as John Riccardo, Chry ler chairman then, went public with the depth of Chrysler's difficulties, a mitting that Chrysler was bleeding red ink. Second-quarter losses reached \$207 million. As summer turned to fall, the news from Chrysler was bleak. Chry ler's $1979 \$ 1.2$ billion loss was the largest recorded in US corporate history. By the end of 1979 , the company was teetering on the brink of bankruptcy. Chrysler owed $\$ 4$ billion, nearly $10 \%$ of all US corporate debt. Eighty tho sand unsold vehicles worth over $\$ 700$ million sat on dealer lots. By the 1980s, Iacocca was heralded as a possible presidential candidate; motivational speakers talked about "Lessons from the Great Leaders: From Hannibal to Iacocca." In 1985, Iacocca wound up on the cover of Time magazine.

In the other hand Arab Potash there is no need to repeat the assessment results before, instead the new leader will focus on assessment of the company after it changed leadership. After1985 a new leadership was assigned to lead and save the Arab Potash. It was the type of transformational leadership. The new leader started from pinpointing problems and deals with it immediately. He started from creating a human resources management to empower employees. Anew overall management structuring and re-engineering took place. Consequently, a great deal of changes took place for the better. The new leader cut cost and provides differentiation. For example, instead of having a costly fleet of trucks to transport raw potash to the Aqaba Gulf for export he built a train rail instead.

The full assessment of the Arab Potash reveals the following:

The value of the Arab Potash Market Company according to the prices of shares in the Amman Stock Exchange on 28/12/2011 was about 3.666 billion dinars

It is worth mentioning that the company's sales in 2011 totaled about one billion dollars, about five times the sales in 2003, while the price of potash worldwide by about 3 times only and the company's value rose 7 times and profits by about 5.5 times It should be noted that the profits distributed since 2004, The strategic partner has reached (102) million dinars, while the total amounts transferred to the government (725) million dinars(Jordan Ministry of Industrial and trade 2014)

- the establishment of a number of derivative industries based on Dead Sea salts. Some of these industries faced problems while others required strategic and global partnerships. (Ministry of Industrial and trade 2014) largest company in the Amman Stock Exchange in terms of market value. 2015 For the first time, APC completed 5,000,000 working hours without lost time injuries, which are defined as injuries that the injured person to take time off for treatment.

\subsection{Before and After Assessment}

\subsubsection{Before:}

When reviewing the records of the company that are kept in several relevant governmental agencies such as the Central Bank, the ministry of industrial and trade, and Amman Stock Exchange, one would face bad news about the company. This researcher was not able to obtain copies of company's supportive charts however, he found some of relevant organizational charts and structure in some of newspapers articles that were written then and kept in archives. as follow:

Arab Potash suffers from having one president, seven vice presidents and thirteen consultants. The company has eleven departments with thirteen advisors and thirteen secretaries. There was no human resource management, rather a personnel office with two employees." (Jordan Ministry of Industrial and trade 2014)

Matter of fact, the place was crowded, ineffective and operates in red due to the very bad management then.

The price or the value of its shares in Amman Stock Exchange was 1.85 Jordanian per share, and this very low value of the company's stock tells the whole story. 
Assessment tools:

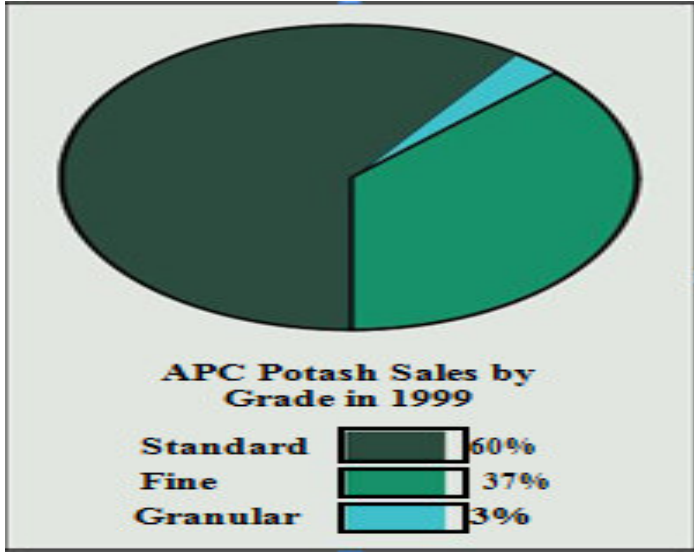

Source: Amman Stock Exchange 1999

As I mentioned earlier that I will use familiar and credible assessment tools to give full and accurate company analysis of Arab Potash, such as : SWOT, evaluating the company's strengths from every aspect. The other one is PESTLE, which refers to: political, economic, social, technological, legal and environmental respectively. In addition, I have used Porter's Five Forces.

The SWOT analysis is one of the most popular strategic analysis models. It gives you a brief look to the all parts of business strength, weakness and any opportunities which will make an add value to the business and threats which will affect at the end.

Once you have identified these, you can assess how to capitalize on your strengths, decrease the effects of your weaknesses, make the most of any opportunities and reduce the impact of any threats.

\section{Opportunities and threats in the external environment}

It's important to remember that opportunities can also be threats - for example, new markets could be dominated by competitors, undermining your position. Equally, threats can also be opportunities - for example, a competitor growing quickly and opening a new market for product or service could mean that company's market will not expand easily

\section{Consolidated Financial Results of the Company from 1/1/2016 till 30/6/2016}

1) Potash Production:

Total quantity produced was 807 thousand MT for the first half of year 2016, compared with 1,106 thousand MT produced for the same period of last year, representing a decrease of $27 \%$. The company expects to reach 1,970 thousand MT by the end of the year, representing $6 \%$ below full year production budget. This drop is mainly due to a maintenance shutdown for one of APC's main plants (Hot Leach Plant) for approximately two months. The monthly capacity of HLP plant is 120 thousand MT. World Production Millions of Metric Tons (KCI)

\begin{tabular}{|c|c|c|c|c|c|}
\hline Country & & 1998 & 1997 & 1996 & 1995 \\
\hline CIS & 12.5 & 11.6 & 11.0 & 9.0 & 9.3 \\
\hline Canada & 13.7 & 15.3 & 14.7 & 13.5 & 15.0 \\
\hline Europe & 7.4 & 7.6 & 7.5 & 8.1 & 8.1 \\
\hline U.S.A. & 1.4 & 1.5 & 1.9 & 1.8 & 2.0 \\
\hline DSW & 2.8 & 2.7 & 2.5 & 2.5 & 2.1 \\
\hline Jordan & 1.8 & 1.5 & 1.4 & 1.8 & 1.8 \\
\hline Others & 1.3 & 1.1 & 1.1 & 0.9 & 0.7 \\
\hline Total & 40.9 & 41.3 & 40.1 & 37.6 & 39.0 \\
\hline
\end{tabular}

2) Potash Sales Quantity:

Total quantity sold was 782 thousand MT for the first half of the year 2016, compared with 1,093 thousand MT sold for the same period of last year, representing a drop of $28 \%$. This drop is mainly due to the slowdown in the global economy and weaker currencies in many potash consuming countries.

3) Sales Revenues:

Consolidated Revenues for the first half of year 2016 amounted to JD 156 million compared to JD 264 million for the same period of last year, a decrease of $41 \%$. This decrease in revenues was mainly attributed to the decrease in potash international prices which are currently at the lowest level in 10 years, and the contraction of demand given the delay in reaching annual contracts with China and India. This drop not only put downward pressure on the revenues, but also forced several international producers to announce shutting down some of their Potash mines, and reducing production volumes 
during 2016.

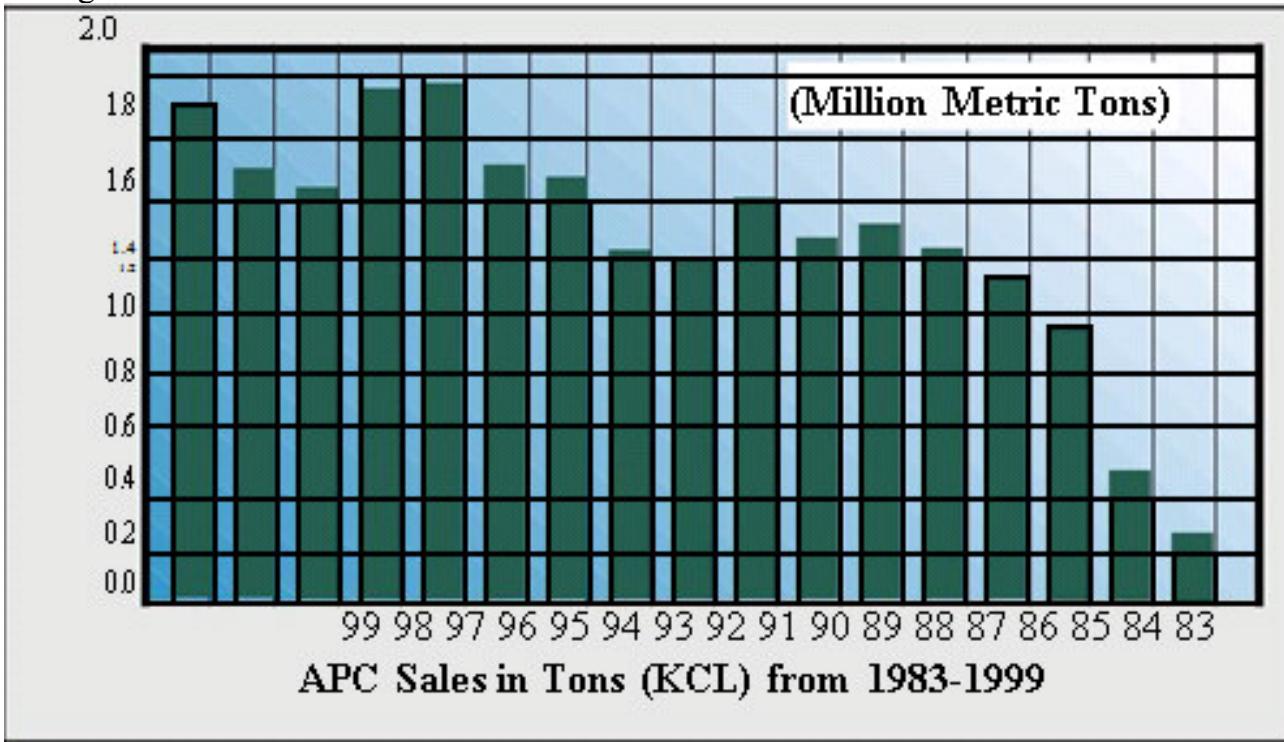

4) Profits:

Consolidated profits before income tax for the first half of year 2016 amounted to JD 30.3 million compared to JD 75.7 million for the same period of last year. Net profit after tax for the same period is JD 28.7 million compared to JD 61 million last year, a decrease of 53\%. The decrease in profits was mainly attributed to the decrease in sales revenues as mentioned above in addition to the decrease in production volume due to the shutdown for maintenance purposes

\subsection{2 after the analysis}

\section{Organization Chart}
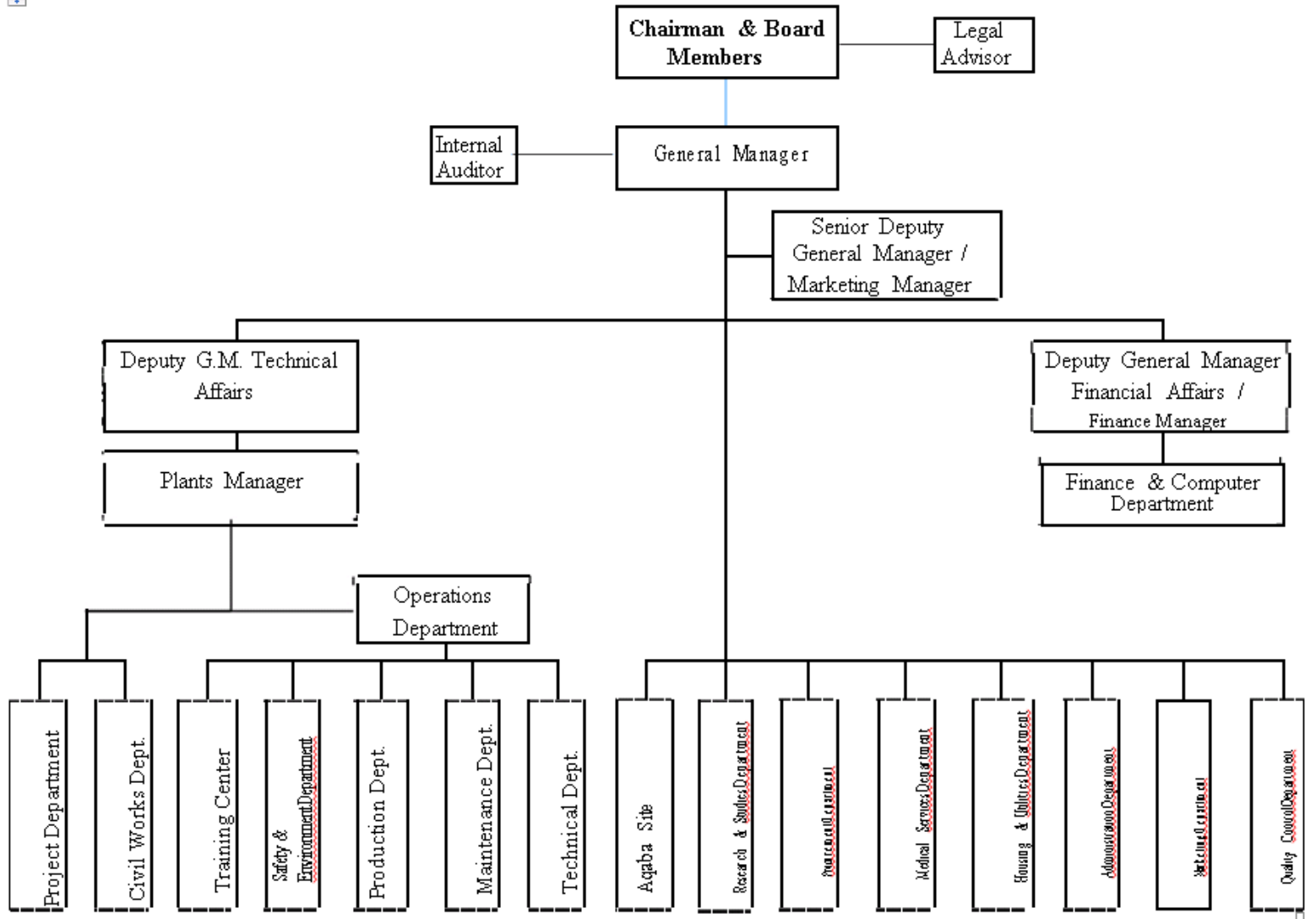

There is no need to repeat the assessment results before, instead I will focus on assessment of the company after it changed management, rather leadership. As it is mentioned earlier after1985 a new leadership was assigned to lead and save the Arab Potash. It was the type of transformational leader ship. The new leader started from pinpointing problems and deals with it immediately. He started from creating a human resources 
management to empower employees. Anew overall management structuring and re-engineering took place. Consequently, a great deal of changes took place for the better. THE new leader cut cost and provides differentiation. instead of having a costly fleet of trucks to transport raw potash to the Aqaba Gulf for export he built a train rail instead. Matter of fact, we benefitted greatly from pestle assessment tool which I applied to give full assessment of the company to give accurate assessment of the company, as follow:

P-political: Jordan is politically very stable kingdom with an excellent responsibility from our King Abdullah II Bin Al Hussein; it is a place which attracts foreign investments from around the world especially from the Gulf states and Saudi Arabia.

Jordan, with all war and terrorists surrounding it, it still sustains its security and safety hence that Jordan is a member in the UN, and has a good relationship with Europe specially with the Great Britain. These are facts known by the entire world. This excellent political condition reflects positively on economy including Arab Potash.

E: Economy: Jordan's economy is free and open economy with a good given chance which reflects positively on exporters and importers in and out of Jordan including Arab Potash

\section{S: Social}

The company has made tremendous strides in the field of public safety and safety of the worker and the employee since 2003 and has made achievements and figures on the international level in this area, and festivities and give gifts to employees after achieving all the goals of safety.

Potash Company to achieve societal responsibilities as a model where includes cash contributions directly to youth clubs, associations, municipalities, trade unions, events, charities and non - governmental company and contribute to the management and financing of a number of projects and initiatives, including the maintenance and perpetuation of some schools and the provision of extra lessons 450 pupils in the area in order to raise the level of their collection. The company provides 58 scholarships annually to its employees, retirees and residents of the Jordan Valley region to complete higher education.

\section{T: technology}

The world is living nowadays in the midst of information and communication revolution. This information technology has touched every aspect of human life: at work, school work place etc. Matter of fact technology has changed the conventional or traditional culture of people into digital culture. regard to businesses, the more information a corporate leader gets the more skilled will be in making wise decisions. With technology, a leader can create innovation in the company in every aspect, area and product. The same is true for Arab Potash, leaders of this company used technology to grow, expand and enhance their product and services quality. Technology enabled Arab Potash leadership to cut costs throughout the company, especially when they constructed a special port in Aqaba to export potash and other Dead Sea salts to global markets. They added another savings in money and time by connecting this port to the Dead Sea by freight trains.

L: legal, The Jordanian laws are flexible and affective and has been introduced from a high knowledgeable people to protect local businesses and attract foreign investments.

E: Environment, most of businesses including industrial companies are environment friendly. There are harsh laws for environment abusers including Arab Potash.

in combination, I like to use Porters Five Forces which usually give a brief and a well know vision for the business demands in future, because his techniques examines the business domain or industry with which an organization operates, and it identifies the pressures that may be brought to bear upon the organization. It is the type of using Five Major Forces framework and it usually applied to suite the products and services.

Industry, asking a lot of question about the level of the products and services against competitors, had the company have any certificates of standards in production

Our company industrial is one of the best industry and easy one with low running cost compared to other ones

New Entrants, is ask about the financial and the possibility to work with lowest money base and get the highest amount of money (decreasing the running cost)

Due to the idea that the company whose opened years and years ago, now a day it owns all the equipment, so the running cost of the equipment is not very high but the services for it is high. As I mentioned earlier I have used Porter's five forces. This analysis showed challenges that Arab Potash is facing. It is a great challenge that comes from a new entrant to the potash production and sale. It is the Israeli Potash company which has been established almost at the vicinity of the Arab Potash on the Dead Sea shores. 
Balanced Scorecard SWOT analysis

\begin{tabular}{|l|l|l|l|l|}
\hline & STRENGTHS & WEAKNESSES & OPPORTUNITIES & THREATS \\
\hline FINANCIAL & Equipment owned & $\begin{array}{l}\text { Need some services } \\
\text { and changes }\end{array}$ & $\begin{array}{l}\text { Lending from bank, and the } \\
\text { money in the account is well } \\
\text { enough }\end{array}$ & $\begin{array}{l}\text { Price decrease } \\
\text { and } \\
\text { cover }\end{array}$ \\
\hline wUSTOMER & Good markets yet & $\begin{array}{l}\text { Buying when they } \\
\text { need }\end{array}$ & Opening new markets & $\begin{array}{l}\text { Wars like Iraq } \\
\text { and Syria }\end{array}$ \\
\hline $\begin{array}{l}\text { INTERNAL } \\
\text { PROCESSES }\end{array}$ & $\begin{array}{l}\text { The total company } \\
\text { are owned by } \\
\text { government }\end{array}$ & $\begin{array}{l}\text { No follow up } \\
\text { Many managers have } \\
\text { come to the company }\end{array}$ & $\begin{array}{l}\text { Keeping the good expertise } \\
\text { people }\end{array}$ & $\begin{array}{l}\text { Salaries } \\
\text { decrease }\end{array}$ \\
\hline PEOPLE & $\begin{array}{l}\text { Knowledgeable } \\
\text { Expertise }\end{array}$ & $\begin{array}{l}\text { Need more training } \\
\text { with the new } \\
\text { methods }\end{array}$ & $\begin{array}{l}\text { Getting an expertise } \\
\text { Leaving } \\
\text { company }\end{array}$ \\
\hline
\end{tabular}

\section{Consolidated Financial Results of the Company for the first half of the year 2017:}

1) Potash Production Volume:

Total quantity produced increased by $50 \%$ and stood at (543) thousand MT in the second quarter of the year 2017 compared to (361) thousand MT produced in the same period last year. Last year, two months of maintenance shutdown took place starting in March for one of APC's main plants (Hot Leach Plant-HLP) that resulted in drop in production. The monthly capacity of HLP is 120 thousand MT. The company produced (1.1) million MT in the first half of the year 2017 compared to (807) thousand MT of the corresponding period of the last year.

2) Potash Sales Volume

The Arab Potash Company sold (550) thousand MT in the second quarter of the year 2017 compared to (463) thousand MT for the same period last year, representing an increase of $19 \%$. The increase in sales was mainly due to the delay in signing the annual contracts with China and India in 2016, noting that the second quarter sales quantities is benefiting from carryover sales from the same 2016 contracts with China and India. The Company's sales improved by $47 \%$ in the first half of this year to reach (1.2) million MT from (782) thousand MT in the same period last year.

3) Sales Revenues:

The consolidated revenues for the second quarter of the year 2017 stood at JD (103) million compared to JD (85) million for the same period of last year with an increase of $21 \%$. The increase in sales revenues was mainly attributed to the higher sales quantities of potash during this quarter which also more than offset the drop-in potash international prices which reached their lowest level in 10 years. The total sales revenue stood at JD (202) million in the first half of 2017 compared to JD (156) million in the same period last year.

\section{4) Net Profit:}

The company achieved a consolidated profit before income tax of JD (20.2) million in the second quarter of the year 2017 vs. JD (4.4) million for the same period last year. The consolidated net profit after tax for 2017 second quarter was JD (16.5) million compared to JD (4.4) million in the second quarter last year which represents an increase of $275 \%$. The increase in net profit is mainly attributed to the higher sales quantities of potash in the second quarter which also more than offset the drop in potash international prices. APC's net profit stood at JD (42.8) million in the first half of 2017 compared to JD (28.7) million of the corresponding period last year

\section{Bibliography}

Abbah M. / 2014 / employee motivation: the key to effective organizational management in nigeria / iosr journal of business and management (iosr-jbm) e-issn: 2278-487x, p-issn: 2319-7668. volume 16, issue 4. ver. i (apr. 2014), pp 01-08

- Bauer T., berrinerdogan (2012) an introduction to organizational behavior / this book was accessible as of december 29, 2012, and it was downloaded then by andy schmitz(http://lardbucket.org)

- Delta publishing company, (2006) understanding and managing organizational behavior / p.o. box 5332, los alamitos, ca $90721-5332$

- $\quad$ eisenhower d. (2011) leadership essay, ed 730

- $\quad$ Jiang X. (2010) how to motivate people working in teams / www.ccsenet.org/ijbm

- John c. maxwell, 2012 , organizational behavior, publisher: stl isbn: 0785270345 
- $\quad$ Lusthaus C., Adrien L., Anderson G., Carden F, and pliniomontalván G., 2002, organizational assessment: a framework for improving performance / international development research centre

- Jordan Ministry of Industrial and trade 2014

- Rashasalama (2017) motivation towards teamwork / phd of public health and community medicine , faculty of medicine ,suez canal university, Egypt

- Shanks N (2012) management and motivation / jones and bartlett

- $\quad$ Andrejchuk, V. (2002). Collapse above the world's largest potash mine (ural, russia).

- $\quad$ International Journal of Speleology, 31(1):8.

- Baumeister, C. and Kilian, L. (2016). Forty years of oil price uctuations: Why the price of oil may still surprise us. The Journal of Economic Perspectives, 30(1):139-1 $\overline{6} 0$.

- $\quad$ Benoit, J.-P. and Krishna, V. (1987). Dynamic duopoly: Prices and quantities. The review of economic studies, 54(1):23-35.

- Gnutzmann, H. and Spiewanowski, P. (2016). Fertilizer fuels food prices: Identication through the oil-gas spread. Available at SSRN 2808381.

- Hamilton, J. D. (2003). What is an oil shock? Journal of econometrics, 113(2):363-398.

- Hamilton, J. D. (2011). Historical oil shocks. Technical report, National Bureau of Economic Research.

- Jenny, F. (2012). Export cartels in primary products: The potash case in perspective. Trade, Competition, and the Pricing of Commodities, page 99.

- $\quad$ Kilian, L. (2008). Exogenous oil supply shocks: how big are they and how much do they matter for the us economy? The Review of Economics and Statistics, 90(2):216-240.

- $\quad$ Kilian, L. (2009). Not all oil price shocks are alike: Disentangling demand and supply shocks in the crude oil market. American Economic Review, 99(3):1053-69.

- Morgan Stanley (2016). Global chemicals.

- $\quad$ Prugger, F. F. (1979). The _ooding of the cominco potash mine and its rehabilitation. In Proc. 5th Symp. on Salt, Hamburg, pages 333- 340 .

- $\quad$ Stuermer, M. (2016). 150 years of boom and bust: What drives mineral commodity prices? Macroeconomic Dynamics, pages 1-16.

- $\quad$ Uralkali (2016). Long term values. responsible growth. integrated report, 2015.

- Whyatt, J. and Varley, F. (2008). Catastrophic failures of underground evaporite mines. In Proceedings: 27th International Conference on Ground Control in Mining, pages 29-31.

- Open Journal of Geology, 2016, 6, 1137-1148 http://www.scirp.org/journal/ojg

- Jordan Department of Statistic (2014) Annual Reports 2010-2014. http://cn.knoema.com/atlas/sources/Jordan-Department-of-Statistics?topic=Jordan

- $\quad$ Natural Resources Authority (2000-2013) Mining Sector Performance during 2011 Compared with the Last Four Years. Natural Resources Authority, Amman, Jordan, 39. http://www.philadelphia.edu.jo/newlibrary/pdf/file33cf0f62b2314d998ec74abc0f825bf4.pdf

- Central Bank of Jordan (2014) Annual Reports (2010-2013). Central Bank of Jordan, 82 p. http://www.cbj.gov.jo/

- Energy and Minerals Regulation Commission (2014) Annual Report of Energy and Mining Sector. www.emrc.gov.jo

- $\quad$ Alrawashdeh, R. and Al Tarawneh, K. (2014) Sustainability of Phosphate and Potash Reserves in Jordan. International Journal of Sustainable Economy , 6, 45-63. http://dx.doi.org/10.1504/IJSE.2014.058513

- Arab Potash Company (2013) Fifty-Sixth Annual Report 2012: Arab Potash Co. 80 p.

- Ministry of Industry and Trade (2000-2014) Annual Reports 2004-2013. http://www.mit.gov.jo/Pages/viewpage.aspx?pageID=181

- Jordan Phosphate Mines Company (2013) Annual Reports 2004-2012. Amman, Jordan. http://www.mit.gov.jo/Pages/viewpage.aspx?pageID=181

- Alnawafleh, H., Al Tarawneh, K. and Alrawashdeh, R. (2013) Geologic and Economic Potentials of Minerals and Industrial Rocks in Jordan. Natural Science , 5, 756-769. http://dx.doi.org/10.4236/ns.2013.56092

- Al Tarawneh, K. (2008) Jordanian Phosphate Mining History. Fifth International Conference of Beneficiation of Phosphates, Rio de Janeiro, Brazil, 45.

- $\quad$ Ramadna, A. (2012) Mining Sector in Jordan, Current Situation and Investment Opportunities. Report of Ministry of Industry and Trade, Jordan.

(2014) Jordan Chamber of Industry. Internal Report. www.jci.org.jo

- Mowafa, T. (2014) The Mineral Industry of Jordan. By Minerals Yearbook. U.S. Department of the Interior U.S. Geological Survey in JORDAN [ADVANCE RELEASE] 2012Minerals Yearbook 